\title{
EPIDEMIOLOGY OF AUTOPSY-REFERRED CASES IN THE NORTH OF PALESTINE (WEST BANK): A RETROSPECTIVE STUDY
}

\author{
BasmaDamiri ${ }^{1}$, Rayyan $\mathrm{Ali}^{2}$, Assad Hijawi ${ }^{3}$
}

1. Department of Drugs and Toxicology, An-Najah National University, Nablus 00970, Palestine

2. An-Najah Forensic Medicine Institute, An-Najah National University, Nablus,00970, Palestine.

3. Department of Medicine, An-Najah National University, Nablus,00970, Palestine

Corresponding Author: BasmaDamiri, Nablus, Palestine, bdamiri@najah.edu

\section{ABSTRACT}

Background: Death registration system in Palestineis incomplete or unreliable in determining cause and manner of death. Autopsy is a more reliable method to uncover the hidden possible underlying causes of death. The main objective of this study is to assess the epidemiology of autopsy-referred cases in the north of West Bank through the study period (2010-2012).Results: Total number of cases was 159 (77.4\% males and 22.6\% females). Natural and accidental deaths were the two leading manners (39\%and 28.9\%; respectively) followed by homicidal (18.2\%) and suicidal deaths (13.8\%).Males contributed to most cases in all manners. Cardiovascular related diseases were leading causes of natural deaths (62.9\%), followed by respiratory diseases $(9.5 \%)$. Trauma was the direct cause of accidental deaths for $45.6 \%$ due to falling down followed by asphyxia and suffocation $(28.3 \%)$ due to accidental burns and trapping in closed places. Hanging was a major cause for suicidal deaths (41\%) followed by intoxication (27\%). In homicidal deaths, fire arm and stab wounds were major causes (35\% for each) followed by manual strangulation and hanging (24\%).According to age group, least number of deaths was in extremes of age (infants $6.9 \%$ and elderly $11.9 \%$ ) and was attributed mainly to natural causes of death. Most accidental deaths were in children, most homicides and natural deaths were middle aged people. However, most suicides were adults. Moreover, $72 \%$ of 
cases were from villages, $5 \%$ from refugee camps and $4.23 \%$ from cities. There was no association between the manners of death and seasons of the year ( $\mathrm{P}$ value0.798). Conclusion: Autopsy is a more reliable method to uncover possible hidden causes of death where it can reveal the actual manner and cause of death that is vital improve public health. As the majority of deaths were natural or unwitnessed, this probably refers to a weak health system. Therefore, we recommend health system development in elderly and in chronically ill. Since most of cases were from villages, improving health care system in rural areas as well as increasing awareness campaigns with toxins and proper storage methods for agricultural pesticides is recommended.

Key words: Postmortem, Autopsy, West Bank, Death, Intoxication

\section{INTRODUCTION}

Mortality data are important for planning, setting priorities, formulating and monitoring health policies in any country to improve health services and systems. In most countries, particularly those with low and middle incomes, death registration is incomplete, and the quality of information on cause of death is highly variable (Mathers et al., 2005, Ravakhah, 2006).This is an important limitation to the development and implementation of policy to improve health. Death registration systems in Palestine have improved greatly over the past two decades. A high proportion of deaths occur outside hospitals and in the absence of medical attention, therefore, reliability of causes of death at registration remains uncertain. As a result, a very substantial fraction of deaths occurring at home are registered with ill-defined causes of death, limiting the utility of registration data for epidemiological research and health policy. This calls for the use of other sources of data to ascertain the cause of death in such cases; and here comes the role of autopsy as one of these sources.

An autopsy, also known as a postmortem (PM) examination or necropsy, is a sequel and a completion of 
the study of disease after death and performed for either legal and/or medical purposes(Madea and Rothschild, 2010, Ravakhah, 2006, Weingart et al., 2000a); moreover, data obtained from autopsy also allow the assessment of more specific issues, which may have noteworthy implications for prevention such as the actual rate of infant injury deaths, which are misdiagnosed as sudden infant death syndrome (SIDS) or the actual risk of unnatural deaths in individuals with acquired or congenital diseases(Lunetta et al., 2007). Therefore, diagnostic pathological autopsies have long been considered the "gold standard" for cause of death determination(Fligner et al., 2011).Establishing manner of death is one of the most important endeavours in forensic pathology(Balaguer Martinez et al., 1998). On the other hand, cause of death is the actual mechanism that produces death which must be distinguished from the manner or mode of death, as these terms are often confused(Driscoll and Edwards, 1985).
Although autopsy rates have declined since 1950s and are generally low in many developed countries, it has been shown in numerous studies that autopsy and PM histopathological examination are the only ones that can diagnose correctly and completely (Ayoub and Chow, 2008, Lunetta et al., 2007, Fligner et al., 2011, Chariot et al., 2000, Kapusta et al., 2011). In Palestine, like many developing countries, autopsy is rare unless conducted in the medico-legal arena. Autopsy as medico-legal practice was in use in different historical periods under the control and oversight of different governing regimes for different political and social uses; therefore, official documents related to autopsied cases are rare. Besides that,autopsies were problematic procedures in Palestinian society due to socio-religious attitudes that refuses autopsy for the belief that it contradicts shari'a and due to the sanctity of the human body(Daher-Nashif). Moreover, local community rejects autopsy for killing in illegal sexual 
relations but was occasionally performed in special cases.

Forensic science is new in Palestine and was established by the coming of the Palestinian National Authority in 1994. It suffers from a shortage of staff, components, and laboratories; therefore, it wasn't before 2005 when Al-Quds University Forensic Medicine Institute was established to cover the southern governorates in the West Bank and another one at An-NajahUniversity in Nablus, which was established in 2006 to cover the northern governorates in the West Bank. Moreover, due to the lack of staff and experience, autopsy results were not reliable until 2010. With return to the Palestinian ministry of Justice database, there were 128 autopsied cases in the West Bank in 2010, 158 cases in 2011, and 162 cases in 2012. Based on this background, scholarly literature on forensic science in the Palestinian society is limited. This research aimed to describe and characterize the mortality data that is related to autopsy in Palestine from the years 2010-2012 in order to build data bases that could help making good decisions to improve care and decrease death rates.

\section{MATERIAL AND METHODS Study design and settings}

A retrospective study was conducted at the Forensic Medicine Institute -AnNajah National University - Palestine, which covers the northern governorates of the West Bank includingNablus, Tulkarm, Qulqilia, Jenin, Salfiet and Tubas.

\section{Study population and sample size}

According to the Palestinian ministry of Justice data base, the total number of autopsied cases from North of Palestine (West Bank part)in the period 2010-2012 was 212 cases (76 cases in 2010; 70 in 2011 and 66 in 2012). Cases were referred to the Forensic Medicine Institute from the North of Palestine in the periods January to March 2010and September 2010 to September 2012. Out of 212 cases, 53 were referred to another forensic medicine institute and the final autopsied cases were 159 . 


\section{Data collection and variables}

Personal profiles of cases (age, gender, place of residency and marital status) were obtained from the identity card included with the autopsy report. Further information (cause and manner of death, signs and symptoms of any premortem illness and its duration, health care seeking, medications used, and admission to a health facility) was taken from final autopsy reports saved in the forensic medicine institute's data base.Autopsies were carried out by a qualified forensic pathologist and consisted of:

Review of history from relatives and/or from medical records (where available), external examination, internal examination of all major organ systems (dissection), and additional studies (histology, microbiology, toxicology) in selected cases as determined by the forensic pathologist.

\section{Ethical issues}

The study was carried out in accordance with the ethical standards, Declaration of Helsinki. Approval was obtained from Institutional Review Board "IRB" at An-Najah National University in Palestine prior to the research conduction.

\section{Statistical analysis}

Statistical Product and Service Solutions (SPSS) (version 19, IBM Corporation) was used for data entry and analysis. Data was described using means and percentages. Pearson Chisquare was used to compare categorical variables where a p-value $<0.05$ was considered statistically significant.

\section{RESULTS}

As observed from Table 1, males constituted majority of the study cases $(\mathrm{n}=123 ; 77.4 \%)$ throughout the study period. 
Table (1): Gender distribution of study cases

\begin{tabular}{|c|c|c|c|c|}
\hline \multirow{2}{*}{ Gender } & \multicolumn{4}{|c|}{ Year } \\
\cline { 2 - 5 } & 2010 & 2011 & 2012 & Total \\
& $\mathrm{n}(\%)$ & $\mathrm{n}(\%)$ & $52(78)$ & $123(77.4)$ \\
\hline Males & $14(61)$ & $57(81)$ & $14(22)$ & $36(22.6)$ \\
\hline Females & $9(39)$ & $13(19)$ & $1 \%)$ \\
\hline
\end{tabular}

- Data are expressed as n (\% of the cases).

$\underline{\text { Age-specific manner of death }}$ distribution

Manner of death is classified into intentional (homicide or suicide), unintentional (accidental), natural and undetermined(Balaguer Martinez et al., 1998).As observed in Table 2, natural and accidental deaths were the twoleading manners (39 and 28.9\%; respectively) followed by homicidal (18.2\%) and suicidal deaths (13.8\%).

According to age group(Table 2), of age (infants $6.9 \%$ and elderly $11.9 \%$ ) and were attributed mainly to natural causes of death (72 and $47.4 \%$ for infant and elderly; respectively).Children from $1-17$ yrs represented $20.8 \%$ of cases; $48.5 \%$ of whichdied in accidental poisoning or unintentional injuries. Most suicidal cases (72.2\%) aged 18-39yrs. Around $45.5 \%$ of the successful suicidal attempts were 25-39yrs followed by $27.2 \%$ from 18-24yrs. Around $13.6 \%$ of suicidal cases were in children $<18 y$ rs. least number of deaths were in extremes

Table (2): Manner-specific mortality by age

\begin{tabular}{|c|c|c|c|c|c|c|c|}
\hline \multirow[t]{2}{*}{ Manner } & \multicolumn{6}{|c|}{ Age group in years / Number of Cases } & Total \\
\hline & $\begin{array}{c}\text { Infant } \\
<1\end{array}$ & $\begin{array}{l}\text { Child } \\
1-17\end{array}$ & $\begin{array}{c}\text { Young adults } \\
18-24\end{array}$ & $\begin{array}{l}\text { Adults } \\
25-39\end{array}$ & $\begin{array}{c}\text { Middle age } \\
40-59\end{array}$ & $\begin{array}{l}\text { Old } \\
\geq 60\end{array}$ & $\mathrm{n}(\%)$ \\
\hline Natural & 8 & 10 & 7 & 10 & 18 & 9 & $62(39)$ \\
\hline Accidental & 3 & 16 & 3 & 11 & 7 & 6 & $46(28.9)$ \\
\hline Homicide & 0 & 4 & 4 & 8 & 11 & 2 & $29(18.2)$ \\
\hline Suicide & 0 & 3 & 6 & 10 & 1 & 2 & $22(13.8)$ \\
\hline Total $\mathrm{n}(\%)$ & $11(6.9)$ & $33(20.8)$ & $20(12.6)$ & $39(24.5)$ & $37(23.3)$ & $19(11.9)$ & $159(100)$ \\
\hline
\end{tabular}

- Data are expressed as $\mathrm{n}$ or as $\mathrm{n}$ (\% of the cases). 
Table 3 explains cause-specific death for each manner. Cardiovascular related diseases were the leading cause of natural death (62.9\%), followed by respiratory $(9.5 \%)$, SIDS (8\%), and GIT, metabolic, and CNS diseases $(6.3 \%$ for each). Trauma was considered the leading cause of accidental deaths due to falling down. It was the direct cause in $45.6 \%$ followed by asphyxia and suffocation $(28.3 \%)$ due to accidental burns and trapping in closed places, drowning (10.8\%), iatrogenic accidents $8.6 \%$, intoxication $(4.3 \%)$ and finally electrical shock (2.2\%).

Five modes of killing were identified in suicidal and homicidal causes.
Hanging was the major cause for suicidal deaths $(41 \%)$ followed by intoxication $(27 \%)$, drowning $(18 \%)$, fire arm(9\%), and finally falling down (4.5\%). In homicidal deaths, fire arm and stab wounds were the major causes $35 \%$ for each) followed by manual strangulation and hanging (24\%). Regardless of the cause of death, $5.7 \%$ of cases were due to intoxication and $6.3 \%$ were due to drowning. It is important to clarify that victims of road traffic accidents and political crisis are not routinely referred to autopsy, which may under estimate the homicidal rate in the region.

Table (3): Cause-specific mortality for referred cases

\begin{tabular}{|c|c|c|c|c|c|c|c|}
\hline Natural death & $\mathrm{n}(\%)$ & $\begin{array}{c}\text { Accidental } \\
\text { death }\end{array}$ & $\mathrm{n}(\%)$ & Homicidal death & $\mathrm{n}(\%)$ & Suicidal death & $\mathrm{n}(\%)$ \\
\hline Cardiovascular & $39(62.9)$ & Trauma & $21(45.6)$ & Fire arm & $10(34.5)$ & Fire arm & $2(9)$ \\
\hline Respiratory & $6(9.5)$ & $\begin{array}{l}\text { Asphyxia \& } \\
\text { suffocation }\end{array}$ & $13(28.3)$ & Stab wound & $10(34.5)$ & Hanging & $9(41)$ \\
\hline Gastrointestinal & $4(6.3)$ & Intoxication & $2(4.3)$ & Intoxication & $1(3.5)$ & Intoxication & $6(27)$ \\
\hline Nervous system & $4(6.3)$ & Drowning & $5(10.8)$ & Drowning & $1(3.5)$ & Drowning & $4(18)$ \\
\hline SIDS & $5(8)$ & Electric shock & $1(2.2)$ & $\begin{array}{c}\text { Manual } \\
\text { strangulation } \\
\text { \&hanging }\end{array}$ & $7(24)$ & $\begin{array}{l}\text { Jumping from } \\
\text { heights }\end{array}$ & $1(4.5)$ \\
\hline Metabolic & $4(6.3)$ & Iatrogenic & $4(8.6)$ & & & & \\
\hline Total & $62(100)$ & & $46(100)$ & & $29(100)$ & & $22(100)$ \\
\hline
\end{tabular}

- Data are expressed as $\mathrm{n}$ or as $\mathrm{n}$ (\% of the total cases). 
Geographical distribution of cases

As detected in Table 4, Jeninhad the largest number of cases $(34.4 \%)$ followed by Nablus (25.2\%), Tulkarm and Tubas. Moreover, according to place of residency, most cases $(72 \%)$ were from villages, $23 \%$ from cities, and $5 \%$ from refugee camps. (20.1\%) and after that, Qulqilia, Salfiet,

Table (4): Manner-based geographical distribution of death cases

\begin{tabular}{|c|c|c|c|c|c|}
\hline & \multicolumn{5}{|c|}{ N of cases } \\
\hline Governorate & Natural & Accidental & Homicide & Suicide & Total no. (\%) \\
\hline Jenin & 16 & 16 & 7 & 11 & $50(34.1)$ \\
\hline Nablus & 21 & 8 & 9 & 2 & $40(25.2)$ \\
\hline Tulkarm & 14 & 8 & 7 & 3 & $32(20.1)$ \\
\hline Qulqilia & 5 & 6 & 3 & 3 & $17(10.7)$ \\
\hline Salfiet & 3 & 4 & 0 & 0 & $7(4.4)$ \\
\hline Tubas & 0 & 3 & 1 & 2 & $6(3.8)$ \\
\hline Others & 3 & 1 & 2 & 1 & $7(4.4)$ \\
\hline Total n (\%) & $62(39)$ & $46(28.9)$ & $29(18.2)$ & $22(13.8)$ & $159(100)$ \\
\hline
\end{tabular}

- Data are expressed as $\mathrm{n}$ or as $\mathrm{n}$ (\% of the total cases).

Gender-based manner of death

\section{distribution}

According to Fig. (1), most of the cases were males in natural deaths (69.4\%), accidental (89.2\%), homicidal (91.7\%) and suicidal deaths (78.9\%). Firearm and stab wounds by malesin their middle age and from villages were the most common methods used in homicidal cases and guns and hanging were in suicidal cases. On the other hand, successful suicidal attempts in females accounted for only $21 \%$ of suicides, and used methods included poisoning with pesticides and less commonly psychotropic drugs. Geographical distribution demonstrated that males were also predominant than female cases in all governorates. 


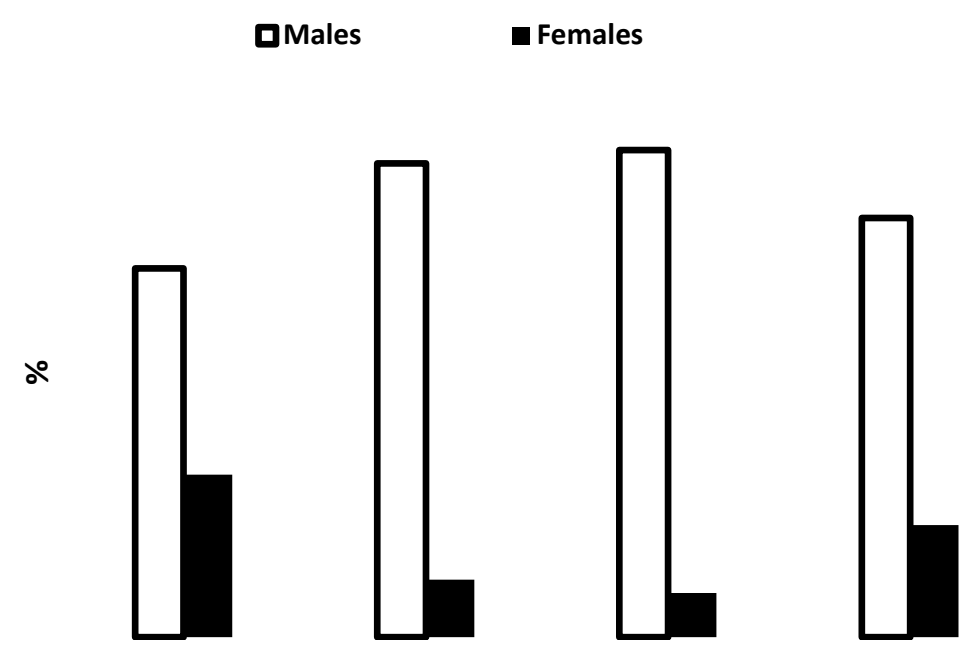

Fig (1): Distribution of cases: Manner of death vs. gender

- Data are expressed as \%

Distribution of cases: manner of death vs. Season

Fig 2 shows the distribution of manners of death according to seasons of the year and Table 5 shows the causes of each manner according to seasons. About 38 cases $(24 \%)$ were in winter, 16of which were due to natural causes; 43 cases $(27 \%)$ were in spring, 17 of which were due to natural causes;33 cases (21\%) were in summer (lowest percent),
15 of which were due to natural causes; 45 cases $(28 \%)$ were in autumn (highest percent)16 of which were accidental while 14 were natural deaths. All SIDS cases occurred in winter and autumn, which was consistent with the hypothesis that viral infection could be one of its causes.There was no association between manners of death and seasons of the year (P value 0.798$)$. 


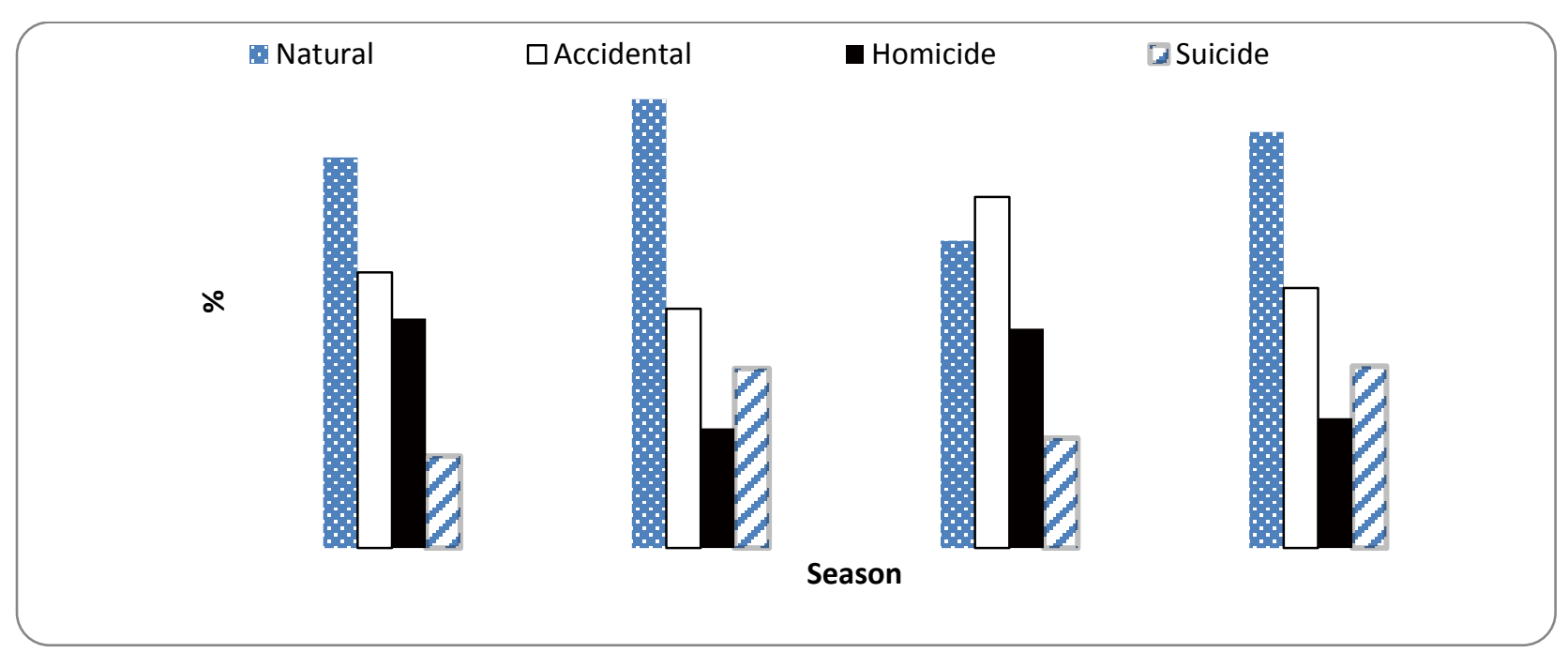

Fig (2): Distribution of cases: Manner of death vs. season

- Data are expressed as \% 
Table (5): Causes of death distributed according to the seasons of the year

\begin{tabular}{|c|c|c|c|c|c|}
\hline \multirow[t]{2}{*}{ Cause } & \multicolumn{4}{|c|}{$\begin{array}{c}\text { no. } \\
\text { Season }\end{array}$} & \multirow[t]{2}{*}{$\begin{array}{c}\text { Tota } \\
\text { no. }\end{array}$} \\
\hline & Spring & Summer & Autumn & Winter & \\
\hline Asphyxia & 1 & 0 & 1 & 2 & 4 \\
\hline Cardiac & 12 & 12 & 5 & 10 & 39 \\
\hline Drowning & 5 & 3 & 1 & 1 & 10 \\
\hline Electric shock & 0 & 0 & 1 & 0 & 1 \\
\hline Fire arm shooting & 3 & 1 & 5 & 3 & 12 \\
\hline Gastrointestinal & 3 & 0 & 1 & 0 & 4 \\
\hline Hanging & 2 & 3 & 0 & 5 & 10 \\
\hline Iatrogenic & 0 & 0 & 2 & 2 & 4 \\
\hline Intoxication & 2 & 2 & 1 & 4 & 9 \\
\hline Manual strangulation & 2 & 0 & 4 & 0 & 6 \\
\hline Metabolic & 1 & 0 & 2 & 1 & 4 \\
\hline Nervous system & 1 & 0 & 2 & 1 & 4 \\
\hline Respiratory & 0 & 2 & 3 & 1 & 6 \\
\hline SIDS & 0 & 1 & 2 & 2 & 5 \\
\hline Suffocation & 3 & 0 & 5 & 1 & 9 \\
\hline Trauma & 8 & 9 & 11 & 6 & 34 \\
\hline Total & 43 & 33 & 45 & 38 & 159 \\
\hline
\end{tabular}

- Data are expressed as number of cases no.

\section{DISCUSSION}

The most fundamental objective of an inquest is to ascertain facts pertaining death. Establishing manner and cause of death is one of the most important endeavours in forensic pathology(Madea and Rothschild, 2010).Cause-specific mortality is also one of the most fundamental metrics of population health. Manner of death is classified into intentional (homicide or suicide), unintentional (accidental), natural and undetermined. 
In this study, natural death went for autopsy because the law in Palestine considers them judicial cases with suspected criminal bases, as they died outside hospitals and there were no witness from a medical provider. The majority of deaths were natural or unwitnessed (died outside hospitals) and this probably refers to a weak health system. Natural and accidental deaths were the two leading manners followed by homicidal and suicidal deaths. Cardiovascular diseases (69.2\%) were the leading cause of natural deathsfollowed by respiratory diseases (9.5\%). Sudden cardiac death (SCD) was responsible for $>50 \%$ of all deaths due to cardiovascular disease, accounting to $>300,000$ deaths each year in theUS(Driscoll and Edwards, 1985, Campbell et al., 2009). Coronary heart disease (CHD) underlies the majority of SCDs in adults (Madea and Rothschild, 2010).

Accidental death was triggered by many causes. Trauma (45.6\%) was the leading causedue to falls from heights followed by asphyxia and suffocationdue to accidental burns and trapping in closed places.Iatrogenic accidents, drowning, intoxication and electrical shock were other causes. This is going well with a prospective cohort study done in China which showed that the leading causes of fatal unintentional injuries are road traffic accidents, drowning, and falls (Rebholz et al., 2011). One of the limitations of this study is that victims of road traffic accidents and political crisis are not routinely referred to autopsy, which may under estimate the homicidal rate in the region. In the US, medical error results in 44,000-98,000 unnecessary deaths/ year and 1,000,000 excess injuries (Weingart et al., 2000b).Regarding iatrogenic causes of death in this study, there were only 4 cases. Deaths occurred during surgical procedures are not referred routinely by law for PM examination. This might underestimate the actual size of the problem, as most of deaths related to previously hospitalized patients are, by law, not referred routinely to PM 
examination except in cases when their families turn to courts and the judiciary.

Manner of death by gender and age provides important health information.Males contributed to most cases in natural (69.4\%), accidental (89.2\%), homicidal (91.7\%), and suicidal death(78.1\%). Geographical distribution demonstratedthat males were also predominant than females in all governorates. These results agree with the Palestinian ministry of health 2011 report that more males than females die each year due to chronic diseases(MOH, 2012, Alrai, 2008). This may also be correlated with the higher mortality risk factors in males rather than females(Weingart et al., 2000b). This is parallel to findings of the World Health Organization (WHO) that revealed, for the 90 countries that provided data to the WHO, suicidal rate was $10.5 / 100,000$ for males and 4.1/100,000 for females(Borges et al., 2010).

Distribution of deaths by age differs markedly between regions (Eliason, 2009, Murray et al., 1994). Most accidental deaths were in children $<18$ years, most homicides and natural deaths were middle aged $(40-<60)$, and most suicides were adults (25-39 years). Similar to other studies(Madea and Rothschild, 2010, Lunetta et al., 2007, Campbell et al., 2009, CDC, 2011), death in infants and elderly was attributed mainly to natural causes. The diagnosis of SIDS was made for unexplained death for children younger than 1 year, with free medical history, and no suspicious death scene or autopsy results. All cases of SIDS occurred in winter and autumn, which was consistent with the hypothesis that viral infection could be one of its causes. Worldwide, natural death is considered the most common manner of death in infants and one of the leading causes of death in children above the age of one in Germany (Madea and Rothschild, 2010). Around $48.5 \%$ of children between 1 and 17 years died in accidental poisoning or unintentional injuries which wasconsistent with WHO and Center for Disease Control and 
Prevention (CDC) in the US(CDC, 2011). More children from 1-14 years die in the US every year from unintentional injuries than from all childhood diseases combined. In 2010, California Department of Health Services reported that every year in California, about 700 children and youth die due to accidental/unintentional

injuries(Rebholz et al., 2011).

Suicide, as a leading cause of death, has increased in young ages and in males more than females (Alrai, 2008, Large et al., 2010, Eliason, 2009). Similar trend was noticed in this study wheremost casesaged 18-39(72.2\%) and $13.6 \%$ of them were below 18 years. Movies and TV shows full with violent scenes watched by children with lack of supervision play a role in increasing suicidal rate in such age group. Moreover, CDC stated that more teens die from suicide than the combined causes of cancer, heart disease, AIDS, birth defects, stroke pneumonia, influenza and chronic lung disease (Gaynes et al., 2004).Similar to other studies (Elfawal, 1999, Dabbagh, 2012, Koronfel, 2002), hanging (41\%) was the most popular method for commitment of suicide.

Approximately, 5.1 million people die each year worldwide and even more people become disabled as a result of injuries (WHO, 2018). In 2010, the CDC reported that suicide kills far more Americans than homicide (Liem et al., 2011). In this study, homicides killed more people $(18.2 \%)$ than suicides $(13.8 \%)$ which was ranked fourth(Balaguer Martinez et al., 1998)with a variable mode of killing in homicidal deaths.In 2001, a Canadian study showed that fire arms and knives were the weapons frequently used by both men and women in the commission of homicide, accounting for the death of more than one in three victims(Dawson et al., 2009). This is similar to what we found out in this study. Firearm and stab wounds were the most frequent causes in homicidal deaths, mostly in the middle age group, males more than females and in villages. This might be related to 
popular customs and traditions that are still prevalent in rural areas, such as tribal bigotry or killing adulterers for honor.Overall, these values should increase the attention of health professionals, the media, and educational campaigns about the risks of homicidal causes.

Five modes of killing were identified in suicidal deaths; hanging, intoxication, drowning, fire arm, and falling down. About $79 \%$ of suicides were achieved by males and using guns or hanging. On the other hand, successful suicidal attempts in females accounted for only $21 \%$ of suicides, and the used methods included poisoning with pesticides and less commonly psychotropic drugs. In other studies, gunshot wounds were the most common in males and poisoning in females together with hanging which was also popular in many countries(Elfawal, 1999, Koronfel, 2002).

Geographical distribution showed that a high proportion of homicidal cases (firearm and stab wounds) came fromrural areas which might be due to the lifestyle, occupation, tribalism, and the nature of the customs and traditions such as killing in illegal sexual relations. All these factors along with others impose obliged pattern of living that could partly explain the high murder rate on one hand, and suicide on the other. Another important point to consider is the widespread work in agriculture, as a substantial number of deaths were due to pesticide poisoning either accidentally or suicidal. Taking of death into consideration, $60 \%$ of cases in Jenin were accidental and suicidalwith the major cause of death intoxication with pesticides.This is going well with the pattern of agriculture that distribute more in the North of the West Bank (Jenin, Nablus, Tulkarm) rather than the South.

\section{CONCLUSION}

Death registration is a vital source of data collection for epidemiological research, development and implementation of policy for health improvement. However, death registration system in Palestine; like 
many other developing countries; is incomplete or unreliable in determining cause and manner of death. Autopsy which involves external and internal PM examination is a more reliable method to uncover possible hidden causes of death where itcan reveal the actual manner and cause of death. Results of this study can be used to adequately support policy development and implementation.

\section{RECOMMENDATIONS}

As the majority of deaths were natural or unwitnessed (died outside hospitals), this probably refers to a weak health system. Therefore, we recommend health system development in elderly and in chronically ill.

Most accidental deaths were children, most homicides and natural deaths were middle aged, and most suicides were adults. These age-related increases in injury rates highlight the vital role of raising national health awareness and establishment of preventive programs in order to decrease injury rate.Since most of cases were from villages, improving health care system in rural areas as well as increasing awareness campaigns with toxins and proper storage methods for agricultural pesticides is recommended.

\section{REFERENCES}

ALRAI, B. (2008):The Palestinian Strategic Report 2007 alZaytouna Centre for Studies \& Consultations.

AYOUB, T.;\& CHOW, J. (2008). The conventional autopsy in modern medicine. Journal of the Royal Society of Medicine, 101: 177-181.

BALAGUER MARTINEZ, J. V.; GABRIEL BOTELLA, F., BRASO AZNAR, J. V., NUNEZ SANCHEZ, C., CATALA BARCELO, T. \& LABIOS GOMEZ, M. (1998):[The role of clinical autopsy in monitoring the quality of the clinical diagnosis in an emergency department]. An Med Interna, 15: 179-82.

BORGES, G., NOCK, M. K.; HARO ABAD, J. M., HWANG, I., SAMPSON, N. A., ALONSO, J., ANDRADE, L. H., ANGERMEYER, M. C., BEAUTRAIS, A., BROMET, E., BRUFFAERTS, R., DE GIROLAMO, G., FLORESCU, S., GUREJE, O., HU, C., KARAM, E. G., KOVESSMASFETY, V., LEE, S., LEVINSON, D., MEDINAMORA, M. E., ORMEL, J., 
POSADA-VILLA，J., SAGAR, R., TOMOV, T., UDA, H., WILLIAMS, D. R. \& KESSLER, R. C. (2010): Twelve-month prevalence of and risk factors for suicide attempts in the World Health Organization World Mental Health Surveys. $J$ Clin Psychiatry, 71: 1617-28.

CAMPBELL, R. M.; BERGER, S. \& DREZNER，J. (2009): Sudden cardiac arrest in children and young athletes: the importance of a detailed personal and family history in the pre-participation evaluation. Br J Sports Med,43: $336-41$.

CDC. (2011):Reproductive mortality, infant mortality [Online]. CDC. Available:

https://www.cdc.gov/reproductive health/maternalinfanthealth/infant mortality.htm [Accessed 2017].

CHARIOT, P.; WITT, K.; PAUTOT, V., PORCHER, R., THOMAS, G., ZAFRANI, E. S. \& LEMAIRE, F. (2000): Declining Autopsy Rate in a French Hospital. Archives of Pathology \& Laboratory Medicine, 124: 739745.

DABBAGH, N. (2012): Behind the statistics: the ethnography of suicide in Palestine. Cult Med Psychiatry,36: 286-305.

DAHER-NASHIF, S.Historical and Present-Day Practices of Forensic Medicine in Palestine: Body, Society, and Science
[Online]. Jerusalem: palestinestudies.org Available: http://www.palestinestudies.org/sites/default/files/jqarticles/Pages\%20from\%20JQ\%2 070\%20-\%20Daher-Nashif.pdf [Accessed 2/2/2018 2018].

DAWSON，M.; BUNGE，V. P. \& BALDE, T. (2009): National trends in intimate partner homicides: explaining declines in Canada, 1976 to 2001. Violence Against Women,15: 276-306.

DRISCOLL, D. J. \& EDWARDS, W. D. (1985):Sudden unexpected death in children and adolescents. $J$ Am Coll Cardiol,5: 118B-121B.

ELFAWAL, M. A. (1999): Cultural influence on the incidence and choice of method of suicide in Saudi Arabia. Am J Forensic Med Pathol,20: 163-8.

ELIASON, S. (2009): Murder-suicide: a review of the recent literature. $J$ Am Acad Psychiatry Law,37: 3716.

FLIGNER，C. L.; MURRAY，J. \& ROBERTS, D. J. (2011):Synergism of verbal autopsy and diagnostic pathology autopsy for improved accuracy of mortality data. Population Health Metrics,9: 25-25.

GAYNES, B. N.; WEST, S. L., FORD, C. A., FRAME, P., KLEIN, J. \& LOHR, K. N. (2004): Screening for suicide risk in adults: a summary of the evidence for the U.S. Preventive Services Task 
Force. Ann Intern Med,140: 82235.

KAPUSTA， N. D.; TRAN， U. S., ROCKETT, I. R., DE LEO, D., NAYLOR, C. P., NIEDERKROTENTHALER, T., VORACEK, M., ETZERSDORFER, E. \& SONNECK, G. (2011):Declining autopsy rates and suicide misclassification: a cross-national analysis of 35 countries. Arch Gen Psychiatry, 68: 1050-7.

KORONFEL, A. A. (2002): Suicide in Dubai, United Arab Emirates. $J$ Clin Forensic Med,9: 5-11.

LARGE, M.; SMITH, G. \& NIELSSEN, O. (2010):Comment on murder-suicide: a review of the recent literature. $J$ Am Acad Psychiatry Law,38: 146; author reply 146-7.

LIEM, M.; BARBER, C., MARKWALDER, N., KILLIAS, $\quad$ M. $\quad$ \& NIEUWBEERTA, P. (2011):Homicide-suicide and other violent deaths: an international comparison. Forensic Sci Int,207: 70-6.

LUNETTA, P.; LOUNAMAA, A. \& SIHVONEN, S. (2007): Surveillance of injury-related deaths: medicolegal autopsy rates and trends in Finland. Inj Prev,13: 282-4.

MADEA, B.;\& ROTHSCHILD, M. (2010): The Post Mortem External Examination: Determination of the Cause and Manner of Death.
Deutsches

$\ddot{A r z t e b l a t t}$

International,107: 575-588.

MATHERS, C. D.; FAT, D. M., INOUE, M., RAO, C. \& LOPEZ, A. D. (2005): Counting the dead and what they died from: an assessment of the global status of cause of death data. Bull World Health Organ, 83: 171-7.

MOH (2012):Palestine Health Status Annual Report 2011. Palestine Health Status Annual Report Palestinian Health Information Center: MOH.

MURRAY，C. J.; LOPEZ, A. D. \& JAMISON， D. T.(1994): The global burden of disease in 1990: summary results, sensitivity analysis and future directions. Bull World Health Organ,72: 495-509.

RAVAKHAH, K. (2006): Death certificates are not reliable: revivification of the autopsy. South Med J,99: 728-33.

REBHOLZ, C. M., GU, D.; YANG, W., CHEN, J., WU, X., HUANG, J. F., CHEN, J. C., CHEN, C. S., KELLY, T. N., DUAN, X., BAZZANO, L. A. \& HE, J. (2011): Mortality from suicide and other external cause injuries in China: a prospective cohort study. BMC Public Health,11: 1471-2458.

WEINGART, S. N.; MCL WILSON, R., GIBBERD, R. W. \& HARRISON, B. (2000a): Epidemiology of medical error. 
Western Journal of Medicine,172: 390-393.

WEINGART, S. N., WILSON, R. M., GIBBERD, R. W. \& HARRISON, B. (2000b):Epidemiology of medical error. BMJ : British Medical Journal,320: 774-777.

WHO, W. H. O. (2018):Falls, Fact Sheet [Online]. Available: http://www.who.int/newsroom/fact-sheets/detail/falls [Accessed 31/8 2018]. 


\section{الملخص}

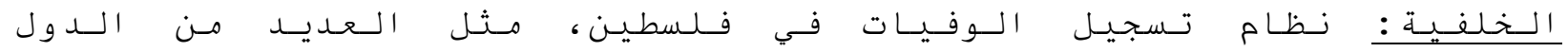

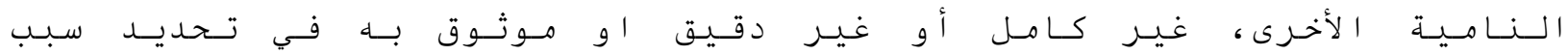

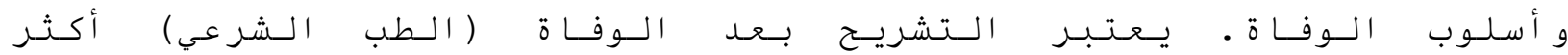

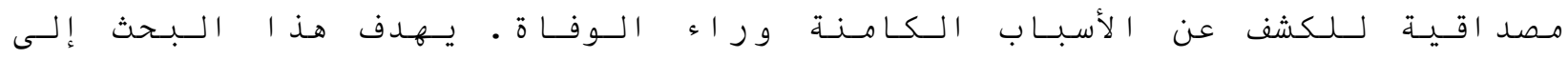

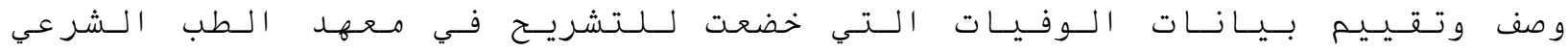

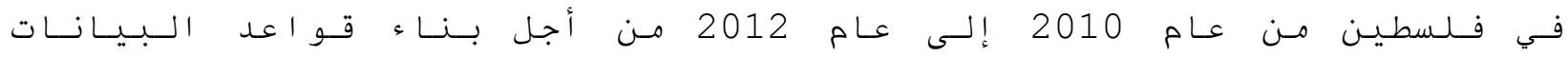

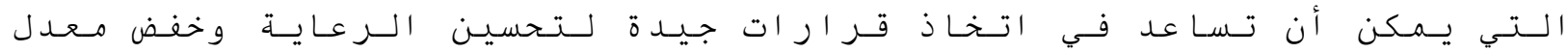

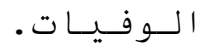

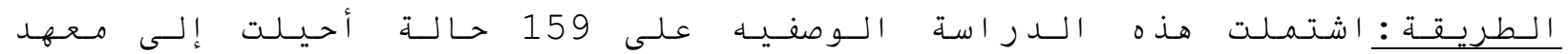

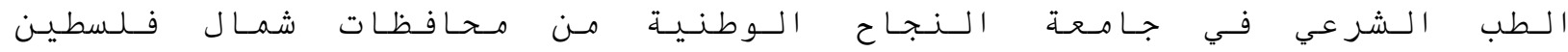

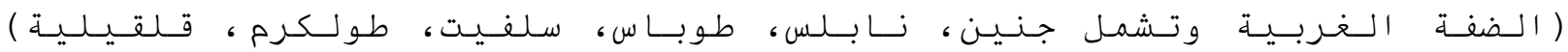

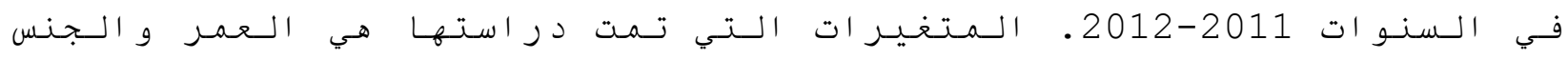

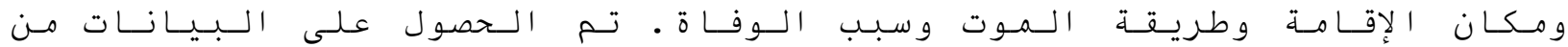

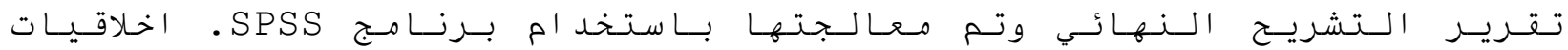

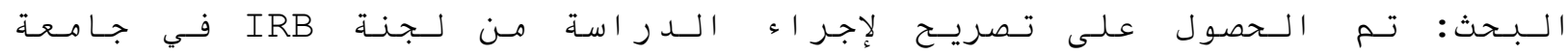

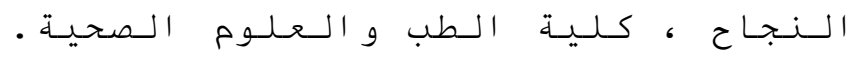

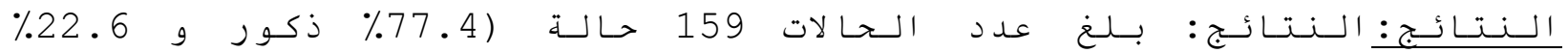

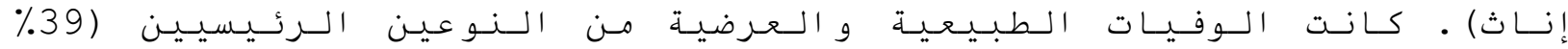

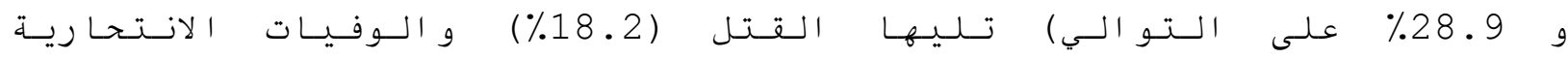

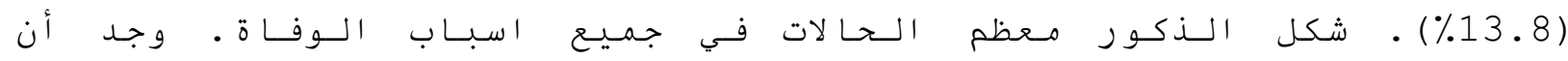

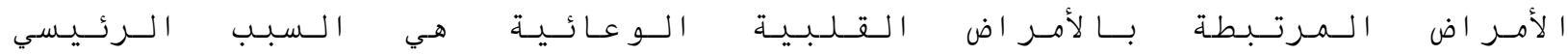

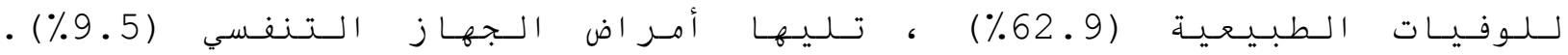

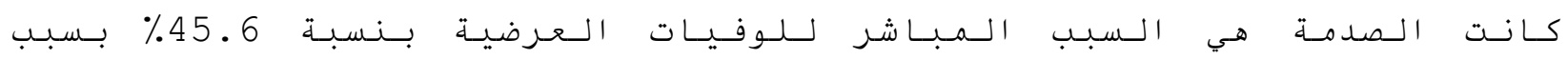

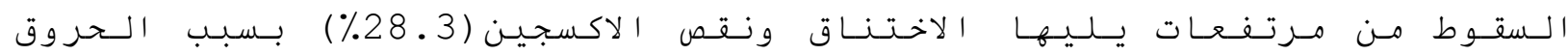

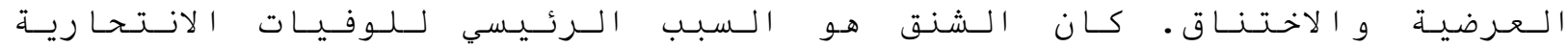

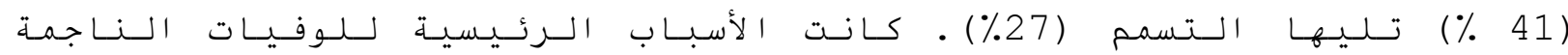




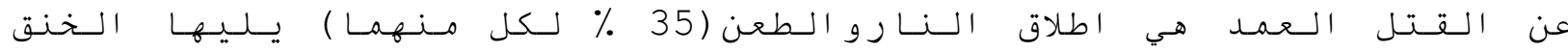

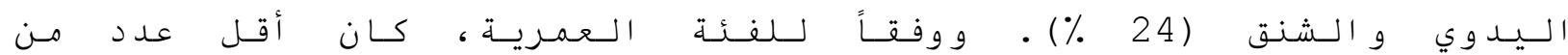

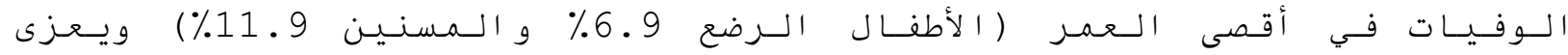

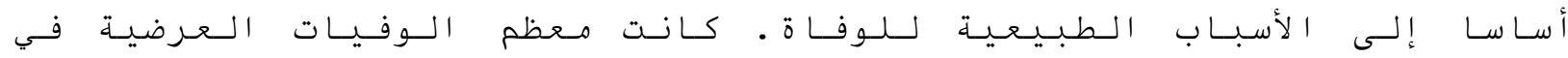

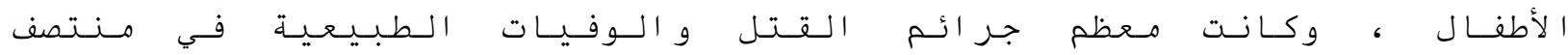
الـعمـر • ومـع ذلك ، كـانـت مـطظم حـالات الانـتحـار مـن الـبـالـغنيـن. علاوة على

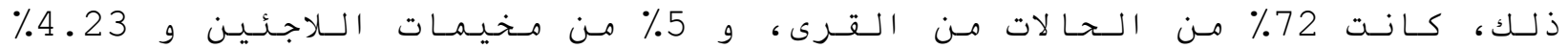

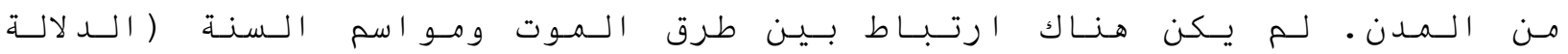

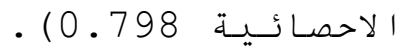

الخلاصة: تشريح الجثة هو طريقة أكثر موثوقية للكثف عن الأسباب المخفية المحتملة للوفاة حيث يمكن أن تكثف عن الطريقة الفعلية وسبب الوفاة. وبما أن غالبية الوفيات طبيعية وليست تحت اشر اف صحي، فمن المحتمل أن يشير هذا إلى نظام صحي ضعيف. لذلك ، فإننا نوصي بنطوير النظام الصحي خصوصا لكبار السن والمصابين بأمر اض مزمنة. وبما أن معظم الحالات كانت من القرى ، يوصى بتحسين نظام الرعاية الصحية في المناطق الريفية وكذللك زيادة حملات التوعية بالسموم وطرق

$$
\text { التخزين المناسبة لمبيدات الآفات الزراعية. }
$$

